\title{
Incubation of the Economic Crisis in Post-Colonial Cameroon 1960-1987: An Experience in State Capitalism
}

\author{
Nixon KahjumTakor ${ }^{1 *}$, Ph.D., George FuhKum², Ph.D \\ ${ }^{I}$ The University of Bamenda \\ ${ }^{2}$ University of Yaoundé I
}

*Corresponding Authors:Nixon KahjumTakor,The University of Bamenda, Cameroon

\begin{abstract}
Toppling from an economic growth rate of 7 percent per annum in the 1970s, Cameroon slumped into an entrenched economic crisis in the mid-1980s which triggered negative growth. The paper upholds that the economic policies and structures that were put in place since independence in 1960 to the onset of the economic crisis in the late 1980s, to ensure development and growth were unhealthy mergers of totalitarian and democratic capitalism. Though some of the intentions bore the necessary parameters and good ordering to ensure balanced growth and development, implementation was entombed in a managerial web that based its planning and performance on a pseudo market. This paper maintains, therefore, that the paradigmatic development plans and parastatal explosion were cosmetic agendums for balanced development. The research builds on data collated from some secondary and primary sources which were interpreted qualitatively and presented thematically.
\end{abstract}

Keywords:Cameroon, Capitalism, Economy, Economic Crisis, Development, Growth, Parastatals, Pseudo Market.

\section{INTRODUCTION}

At independence, most African countries were in dire need of an economic development model to replace the colonial system. Some of the leaders of the newly independent states notably, KwamehNkrumah of Ghana, Julius Nyerere of Tanzania and SekouTouré of Guinea consequently enacted economic development schemes sturdily patterned along African socialism. The need to structure a new economic paradigm was premised on the fact that several years of colonialism had rendered Africa a victim of European exploitation which had as correlate,underdevelopment. ${ }^{1}$ It was also based on the fact that colonialism had not given Africans, the opportunity to adequately showcase and invest indigenous know-how and to aptly develop their tender independent economies.

The state obviously took its responsibility to steer the economy towards growth and development. Such implication of the state in economic affairs is essentially state capitalism that Pollock considers as a social and economic governing order differing on two variants; the totalitarian and democratic forms. ${ }^{2}$ In the totalitarian form of State capitalism, the state is the power instrument of a new ruling group which coordinates production and distribution and uses a combination of old and new strategies including a 'pseudo market' for regulating the economy. ${ }^{3}$ Conversely, in the democratic form of state capitalism, the State has the same controlling functions, but it is controlled more by the people. It is based on institutions which prevent the bureaucracy from transforming into a totalitarian one. ${ }^{4}$ It is from this vantage point that the paper examines the experience of post-independence Cameroon to define and implement its economic development road-map. This is in a bid to appreciate the extent to which state-controlled policies plunged the country into economic malaise.

\footnotetext{
${ }^{1}$ This position is clearly expounded in Walter Rodney, How Europe Underdeveloped Africa (London: BogleL'Ouverture Publications, 1972).

${ }^{2}$ Friedrich Pollock, "State Capitalism: Its possibilities and limitations" in AndrewArato and Eike Gebhardt, Eds. The Essential Frankfurt School Reader (New York: Continum, 1982):72-73.

${ }^{3}$ Ibid.

${ }^{4}$ Ibid., 73 .
} 


\section{BACKGROUND}

At the independence and reunification of Cameroon in 1960 and 1961 respectively, the new state initiated an economic development road map different from the legacies left by the British and French United Nations administering authorities. It was centrally behind this context that the First Republic of Cameroon under President AhmadouAhidjo from 1960 to 1982 shouldered the colossal responsibility of devising a development plan which rested on an assemblage of factors.More importantly it was fashioned to respond to an African-oriented development paradigm.

From every indication the economic strategy of planned liberalism and self-reliance of President Ahidjocreated milestone developments which visibly showed that the economy of the country was on an unalterable path to growth. The indicators in many respects were symptomatic, especially in the second half of the 1970s, which marked the discovery and transformation of oil in the National Refinery Company (SONARA) in Limbe. The parastatal was incorporated as a major national income earner in the 1980s and envisaged to produce 4 billion tons of crude oil by 1985. It suffices here to mention that given the vision of the First Republic, the period (1960-1970) could be described as the decade of strategic economic planning while that from 1970 to 1980 was more or less gauged as anera of economic growth. This was more indicative because, the country enjoyed an economic growth rate that peaked to 7 percent per annum in most part of the 1970s. ${ }^{5}$ From this growth rate the economy went into an all-time low economic performance, indicating a reversal of the growth trend.

The reasons for the economic crisis have been variedly presented by scholars. Tchounguiet al. argue that it came as a response to the global shift in the market forces of primary (mainly agricultural) producewhich contributed to the brute Gross National Income. Describing the situation from this perspective, they hold that the persistent weakness in the markets for raw materials and its effects on public revenue frustrated attempts to halt the deterioration of the economic and financial situation which was manifested in a build-up of outstanding government debts and lack of liquidity in the payment system. Stressing further on the financial system, they conclude that: "the situation was aggravated by the fact that most of the income from exports was expressed in US Dollars, of which the price against the Franc CFA dropped by about 40 percent after June 1985."

Konings for his part opines that the first President of Cameroon, AhmadouAhidjo created a political leadership based on hegemonic alliances that had vested interests in the status quo. It was inclined to resisting any economic and political liberalization measures which threatened the control over stateresources and rent-seeking activities. ${ }^{7}$ To this, Awung and Atanga ${ }^{8}$ argue that political considerations had a negative impact on economic performance in postcolonial Cameroon. They hold that patronage politics and a large unproductive civil service contributed to the economic crisis. Like Konings, theseauthors support the view that patrimonialism was at the root of the crisis. Judging from these perspectives, the authors are unanimous that, President AhmadouAhidjo created a setting of crony capitalism that led the country into poor economic performance.

The putative reasons advanced for the economic crisis in this connection therefore appear to converge on disparaging circumstances in the international economic arena and domestic policies. Contrary to the hasty conclusions that the era of the first Republic (1960-1982) was a model of sound and viable economic policies, the paper maintains that the economic policies and structures that were put in place to ensure development and growth of Cameroon's economy was an unhealthy merger of totalitarian and democratic capitalism. It argues that while some of the intentions had all the necessary parameters and good ordering to ensure economic growth and development, the implementations were encased in managerial cohorts that based its planning and performance on a pseudo market. The paper therefore

\footnotetext{
${ }^{5}$ V.G.Fanso, Cameroon History for Secondary Schools and Colleges vol 2: The colonial and post-colonial periods (London and Oxford: Macmillan Cameroon, 1989):184.

${ }^{6}$ R.Tchoungui, Steve Gartlan, et al., "Structural adjustment and sustainable development in Cameroon." (London: ODI Working Paper 83, August 1995): 40-41.

${ }^{7}$ P.J.J. Konings, "The Post-Colonial State and economic and political reforms in Cameroon," in A.E. FernándezJilberto, and A. Mommen (Eds.), Liberalization in the developing world: institutional and economic changes in Latin America, Africa and Asia (London/New York: Routledge, 1996): 255.

${ }^{8}$ W. J. Awung and M. Atanga, "Economic Crisis and Multi-party Politics in Cameroon," Cameroon Journal of Democracy and Human Rights, Vol 5. No. 1 (June 2011): 94-127.
} 
maintains that the paradigmatic development plans and parastatal explosion were cosmetic agendumswhich in substance were not ordained for long-lasting development.

\section{The Five Years DeVelopment Plans: An ASSESSMENT}

As from 1960 when Ahidjobecame the pioneer Presidentof Cameroon, he articulated different strategies to build an independent strong and viable economy. Ahidjo, considered that it was pointless to talk development in the absence of the economic decolonization of African States. Heformulated his economic development philosophy based on planned liberalism, self-reliance, balanced development and social justice. These main objectives were inserted into a wider project called: "Five Years Development Plans". Five Years Development Plans had lofty objectives and crucial targets to meet, which culminated to giving the Ahidjo era, praises of a carefully conceived economy. They were adopted as catalysts for the rapid transformation of the territory. Although centralized, they were fairly democratic as these were in synergy with the authorities, producers, consumers, and in the final analysis, the whole population. ${ }^{9}$ President Ahidjo earmarked this paradigm, to pursue the path of economic development initially envisaged by the French, which laid conditions for public investment and facilitated the flow of development assistance from foreign partners.

It was in view of the foregoing that a 20 year plan was elaborated to run from 1960.This was initially done in two mid-term phases called the First and Second Five Years Development Plans. ${ }^{10}$ The First Plan from July 1960 to June 1965 was produced by a French research and planning group, without adequate preliminary study to accommodate the entrance of West Cameroon into the total economy of the Federation. ${ }^{11}$ There was the lack of any comprehensive feasibility studies of possible development projects in former West Cameroon at the time and this made it difficult to extend the plan immediately to that state. The total planned investment in East Cameroon projects was earmarked at 53 million Francs CFA. This plan was equally unrealistic in some of its provisions in that the results achieved, only did partially correspond to its stated aims in domains like infrastructure, public education, health and housing. Very little was met in the field of agriculture, which was one of the plan's key points of emphasis. ${ }^{12}$ The First Plan permitted the creation of structures necessary for the success of the second plan. It did also serve as a "period of adaptation" for subsequent development plans. ${ }^{13}$

The Second Five-Year Development Plan was elaborated under the auspices of the Federal Government. The plan was to remedy the defects and failures of the first plan. It envisaged a total investment of 165 million francs CFA, amounting to more than three times that scheduled for the first plan. Of this amount, 45.6 percent was devoted to increasing overall production in the country, 35.1 percent for infrastructural development, 15.8 percent for social equipment and 3.5 percent for administrative cost and studies. ${ }^{14}$ Agriculture was given a pride of place. This explains why the plan was named the "Peasant Plan", to mean that greater emphasis was placed on agriculture. The Plan further called for the acceleration of agricultural commercialization, reform and reorganization.

An important facet of the Plan involved the radical improvement of peasant export production through the diversification of cash crops. Major cash crops like cotton, cocoa, coffee and others were increased significantly. Wood, meat and livestock were also exported in greater quantities. Efforts were made to increase the production of tea, rubber and palm products. These crops were marketed by cooperatives in both parts of the country. The Federal Government created agricultural modernization centres in the five geographical areas of the country to coordinate development research and technical aid relating to the principal crops grown in these areas, served by the five centres. ${ }^{15}$ The plan also

\footnotetext{
${ }^{9}$ A. Ahidjo, The Political Philosophy of AhmadouAhidjo (Monte Carlo: CNU Political Bureau, 1968): 82.

${ }^{10}$ H. Philippe, Analyse du sous-développement en Afrique noire: l'exemple de l'économie du Cameroun (Paris : Presses Universitaires de France, 1968) : 249-254.

${ }^{11}$ V. G. Fanso, Cameroon History for Secondary Schools and CollegesVol.2: The Colonial and Post-Colonial Periods (London, Macmillan Publishers, 1989): 170.

12 A. W. Ndongko, Planning for Economic Development in a Federal State: The Case of Cameroon, 1960-1971 (Munchen, Welt Form Verlage, 1975): 132.

${ }^{13}$ V.T. LeVine, The Cameroon Federal Republic (Ithaca and London: Cornell University Press, 1971): 163.

${ }^{14}$ Ibid., 164.

${ }^{15}$ Ibid., 166.
} 
called for the establishment of regional development structures, much like the "Small landholders development authorities" in Rwanda and Malaysia, which were going to combine plantations and agro-industrial structures. ${ }^{16}$ The major issue with the First and Second Plans was how to fund the various projects earmarked.

The Third Five-Year Development Plan set out to extend the project on creating large scale plantations and agro-industrial structures. Apart from creating and extending large scale structures, projects of integrated development were equally established, to operate with the active participation of the populations concerned. One of the main aims of the Third Plan was to increase production and productivity of all sectors of the economy with significant investment expenditures directed towards the private sector.

From the 1970s, greater attention was placed on agricultural development, urged by the fact that industrial development was costly and slow in reducing poverty and stimulating socio-economic development. ${ }^{17}$ These difficulties were caused by the fact that there was a production gap, due to unfavourable climatic conditions and simultaneously a fall in the prices of some basic products in the international market.In the frameworks of the second and third development plans, government action was geared towards promoting high and equilibrium growth, principally in the domains of agricultural modernization, development of industries, and the acceleration of collective equipment. ${ }^{18}$

Five-Year Development Plans were out to reduce socio-economic disparities between regions of the country. Ndongko argues that, Cameroon's policy of planning was out to "assert, symbolize and strengthen national unity." "For Amin, this was hardly achieved as the plans instead established the basis of inequalities with some sectors and regions favoured against others. ${ }^{20}$ In the third plan, 63 percent of the total investments were allocated directly to productive projects comparing with 46 percent in the second plan. ${ }^{21}$ It can be argued that the private sector did not develop as was expected, due to no solid base for its development. The plans wererather presentations of lists of items to be done, which were never fully completed or whose operationalization were determined by political dictates.

It was in this backdrop that the third (1971-1976) and fourth (1976-1981) plans came to moderate the export sector as well as the discovery of crude oil. Indeed the early 1980 s were known to be Cameroon's golden years. The economy remained dependent on agricultural exports through 1977, but the situation changed when oil exploitation started in 1978.Taking into consideration the agricultural and pastoral vocation of Cameroon at the time, rural development was given priority. This explains why the Third Plan was baptized "production and productivity plan". The Plan was drawn around a certain number of strategic operations, mainly directed towards the public sector aimed at breaking the principal impediments of economic and social development in the country. ${ }^{22}$

In the framework of the Plan, government extended existing plantations and agro-industrial structures, such as the Cocoa Development Corporation (SODECAO), Cameroon Development Corporation (CDC) and Cameroon Society Palm Groves (SOCAPALM), while others were created like the Cotton Development Corporation (SODECOTON), Upper Nun Valley Development Authority (UNVDA), Rice Growing Expansion and Modernisation Company (SEMRY)and othersto encourage and promote cash and food crop production. ${ }^{23}$ Ndongkoestablished that one of the most remarkable events in Cameroon's political economy was the promotion of agro-industrial enterprises, based on plantation production. ${ }^{24}$ The government found the need for harmonious integration of developmentactivities on

\footnotetext{
${ }^{16}$ Ahidjo, Fondements et perspectives du Cameroun (Paris : Saint Lambert, 1976) :33.

${ }_{17}^{17}$ J. Seitz, The Politics of Development (New York, Basil Blackwell Inc, 1988): 15.

${ }^{18}$ Joseph CheKangolo, 70 Years (Interview) Former Secretary of State for Interior, West Cameroon, Wum, $23^{\text {rd }}$ November 2006.

${ }^{19}$ A.W.Ndongko, "Regional Economic Planning in Cameroon", Research Report No. 21, The Scandinavian Institute of African Studies, Uppsala, Sweden, (1974): 6.

${ }^{20}$ A. A. Amin (ed.), "Cameroon's Economy and Reforms in Developing a Sustainable Economy in Cameroon" (CODESRIA, Dakar, 2008):81-82.

${ }^{21}$ Ibid.,81.

${ }^{22}$ NAB, File No. DVA/J.2/2, (Qb/a 1960), "Five Years Development Plan" (1960): 3.

23 Ibid.,43.

${ }^{24}$ A.W.Ndongko, Labour Resistance in Cameroon: Strategies and Labour Resistance in the Agro-Industrial Plantations of the Cameroon Development Corporation (African Studies Centre, Leiden, 1993):16.
} 
account of geographical, historical, socio-cultural and demographic differences, launched to be executed with the active participation of the populations. ${ }^{25}$

The importance of youths in the development process of the country was for the fact that external assistance did not meet the cost of development plans. Total national savings were too slender to permit any hopes. There was reason therefore to take advantage of the most precious means at Cameroon's disposal, namely the unused labour of the thousands of Cameroonian youths in the rural areas. ${ }^{26}$ This labour force was going to measure Cameroonians' efforts and find a solution for the problem of 'disguised unemployment' which was common in the country side. Cameroon was determined to remain a predominantly agricultural country given that most of the population was living agricultural activities.Giving priority to agricultural growth as it was at the time is reminiscent of Anderson and Lorch's views, which hold that:

... very few countries, particularly in the developing world have experienced rapid economic growth without agricultural growth either preceding or accompanying it. This is because agricultural growth is a catalyst to broad-based development. At the micro level, for instance, it provides eventual savings for entrepreneurial development in the informal sector. At the macro level, it provides raw materials which are a strong base for industrial development. ${ }^{27}$

The State intervention in the agricultural sector was direct and indirect. Indirect intervention could be seen as a continuation of the French and British colonial policies through marketing boards which had a monopoly over the agricultural export trade. Through structures like the National Produce Marketing Board (NPMB) this strategy allowed the government to retain a fraction of the nominal world market prices of export crops to finance public consumption and investment needs. ${ }^{28}$ This policy was coupled with guidance of farmers by providing subsidized inputs through parastatals.

Direct intervention involved state corporations, controlling activities formerly carried out by private enterprises. The government sought to increase agricultural productivity through the establishment of the modern sector involving the expansion of plantation farming organisations like the CDC and the Cameroon Sugar Company (CAMSUCO).Being one of the main pillars of agricultural policies in Cameroon; the Third and Fourth Five Years Development Plans (1971-1981), allocated not less than 60 percent of the public funds reserved for agricultural development to the agro-industrial sector. ${ }^{29}$ In spite of these well-intentioned and context relevant strategic vision of the country's economy, the performance did not meet the anticipated dream. Jean Claude Willame, for instance noted that, planned liberalism "was more a shopping list of desirable public sector investment projects for interested financing bodies and industrialists than the rigorous exercise in integrated financial, economic, and social allocation it was theoretically intended to be." ${ }^{30}$

\section{AtTendant Consequences of ApPropriated Policies: The 'DebT trap'}

Early in the period after independence, underdeveloped countries engaged in seeking means for rapid development. This great desire had one main obstacle: financing growth and development. Mboudou ${ }^{31}$ argues that financing the growth and development of a country during that period depended much on mobilizing the necessary financial resources. Several freshly independent countries depended more on external sources for financing developmentbecause internal resources were apparently insufficient. ${ }^{32}$ Such a mechanism gained its roots from the colonial era.

\footnotetext{
${ }^{25}$ Joseph MgbwahNgoh, 64 Years (Interview) WADA Extension Carpenter, Wum, 5 January 2010.

${ }^{26}$ Ahidjo, As Told by AhmadouAhidjo(Paul Bory, Monaco, 1968):58.

${ }^{27}$ P. Anderson and R.P. Lorch, Agricultural Growth is the Key to Poverty Alleviation in Low Income Developing Countries, In the Unfinished Agenda: Perspectives on overcoming Poverty and Environmental Degradation (Washington D.C, 2001):87.

${ }^{28}$ E. Douya, "Cotton Supply Response in Cameroon", in (CODESRIA, Dakar, 2008):66.

${ }^{29}$ Ndongko, Labour Resistance in Cameroon, p.16.

${ }^{30}$ Cited in M.G.Jürg, "Cameroon's Neopatrimonial Dilemma," Working Paper No. (Zurich:Center for International Studies, August 1999):12-13.

${ }^{31}$ A.M. Mboudou, «Le financement du développement au Cameroun » (Thèse de Doctorat de 3éme Cycle, Sciences Economiques, Université de Yaounde, 1981):2.

${ }^{32}$ G.Ngango, Les investissements D'origine extérieur en Afrique noire Francophone: Statut et incidence sur le développent (Paris, Présence Africain, 1973):319-320. Cited in Mboudou, «Le financement du développement au Cameroun, » p.2.
} 
In French Cameroon for instance, public development projects were financed mainly by the Investment Fund for Economic and Social Development, (hereafter, Fondsd'Investissement pour le DéveloppementEconomiqueet Social (FIDES). Two development plans were put together with assistance from this structure between 1947 and 1959, amounting to 96 million Francs CFA. ${ }^{33}$ Southern Cameroons on her part drew up a five year development plan covering the period (1955-1960), with capital grants from Britain amounting to 8.8 million pounds. ${ }^{34}$ This is why after reunification, the bulk of West Cameroon trade remained for a long time with Britain. ${ }^{35}$

LeVine in his analysis of development plans supposes they were utopian in naturegiven that Cameroonian authorities depended largely onexternal sources for their financing. ${ }^{36}$ The resources for financing the various projects in the plans could however have in principle, been provided by drawing on domestic resources, through restricting consumption via higher tax rates or utilising the idle resources of the country, but the government of Cameroonhowever chose to finance development throughinternal and external resources sincethe total planned investments of the first two plans far exceeded available domestic savings. The planners relied more on direct private foreign capital investments and public foreign loans and grants to fill the gap. ${ }^{37}$ Sikod intimates that the first plan was drawn from 72 percent of external financing, 37 percent for the second, 25 percent for the third, with it remaining important in the fourth and fifth plans. ${ }^{38}$

Much of the financing came through bilateral agreements and there was the possibility that these sources, especially from France, could either not be maintainedor discontinued as time went by. In the face of such speculations, the alternative was increased dependence on diverse multi-national and/or international aid and investments.Foreign public aid to Cameroon was therefore accepted no matter its source of origin on condition that it was not linked to any political obligation. ${ }^{39}$ Henry however warns that: "The net result of this reorganisation may well be a net decrease in the aggregate volume of aid received by the recipient country and not the expected increase." 40

The essence of external funding in Cameroon did not however mean a lack of internal sources to effectively finance development. The problem was the lack of adequate economic policies, properly mobilized and orientated to the needed areas of the national economy. In most African states at the time, potential savings had not been totally transformed to effective reserves. In some cases, some of the savings made were poorly used, while some were transformed to sumptuous and ostentatious, instead of productive expenses. ${ }^{41}$ This became so heavy on the economy despite the discovery of offshore oil deposits in the Gulf of Guinea, the mid-1970s affected Cameroon's once predominantly agrarian economy and society. It was hoped this discovery and exploitation would enable a positive growth and help meet Cameroon's debt burden. This was howevernot the case as this rather negatively shaped the behaviour of the governing elite especially in their management of parastatals. ${ }^{42}$

\section{Parastatal Drain}

Cameroon just like many African states earmarked parastatals as catalysts of rapid development at independence. In this backdrop, the state played a central role in promoting economic and social development due to the absence of a buoyant private sector. ${ }^{43}$ For this reason, development efforts

\footnotetext{
${ }^{33}$ A.W. Ndongko, Regional Development Policy in Cameroon (the Faculty of Law and Economics University of Yaoundé, 1975):30.

${ }^{34}$ Ibid.

${ }^{35}$ NAB, File No. PMO 422 (Qb/a 1962/2), "General Economic Situation in West Cameroon Arising from Reunification", (1962):92.

${ }^{36}$ LeVine, The Cameroon Federal Republic, 164.

${ }^{37}$ Ndongko, Planning for Economic Development in a Federal State, p. 131.

${ }^{38}$ F.Sikod, "The Completion point of the HIPC Initiative: what it means for the Cameroon Economy, A Presentation at Hilton, Sponsored by the British Council" ( 2006 ).

${ }^{39}$ NAB, File No. 271/ S.2 (Qb/a 1969), “Third Five Year Development Plan, 1971-76”, (1969):148.

${ }^{40}$ P. M. Henry, "The United Nations and the Problem of African Development", International Organization, XVI, No. 2, (Spring 1962):162, Cited in Levine, The Cameroon Federal Republic, p.164.

${ }^{41}$ Mboudou, «Le financement du développement au Cameroun », p.2.

${ }^{42}$ Bertelsmann Stiftung, Cameroon Country Report, BTI, 2012, p.3., in http://www.bti-project.org, retrieved on 20/07/2013.

${ }^{43}$ A. Ahidjo, As Told by AhmadouAhidjo. 54
} 
were championed by public rather than private firms, even in fields where the state had neither requisite expertise nor comparative advantage over the private sector. ${ }^{44}$ This scenario fits the description of Jua who mentions that "the state in this role served as an entrepreneur." 45

As a public entrepreneur, the State by 1987 had well over 200 state corporations covering every sector of the national economy. These included among others: the Cameroon Shipping Lines (CAMSHIP), the Cameroon Development Corporation (CDC) the National Petroleum Corporation (SNH) , the Cameroon Telecommunication sector(INTELCAM), the National Water Corporation(SNEC), Inter Community fund for Equipment and Mutual Assistance (FEICOM), the National Social Insurance Fund (CNPS), the National Oil Refinery Corporation (SONARA), the National Cotton Development Corporation (SODECOTTON) and the National Electricity Corporation (SONEL). ${ }^{46}$

Important as these parastatals were, a fair share of them remained unproductive in terms of profit maximization. Indicative of this scenario was the performance some 19 firms in the Agro-industrial sector where SNI had equity. It was noticed that most of them were working at loss by 1982-83. Prominent among them were the wood and wood product industries were five of the six of them controlled by the SNI lost 39 billion Francs CFA during the 1982-83 fiscal year. ${ }^{47}$ For these parastatals to survive, they were to be subject to annual state subsidies. Konings observes that their dependence upon the state for subsidies became a permanent rather than transient feature. This furthered ischaemia at the state treasury as by 1987 , annual parastatal subsidies amounted to about 150 billion Francs CFA. ${ }^{48}$

The reasons for the dismal performance of parastatals were in the most part linked to patronageoriented management. State corporations were seen at the time as bases to galvanize political support and reward political acolytes. Hiring into parastatals was done at the discretion of General Managers, based on ethnic and/or political affiliations. Awung and Atanga maintain further that because parastatals were used to promote loyalty rather than economic goals, General Managers could stay in their positions as long as possible. ${ }^{49}$ Rational reflection would have dictated that these parastatals be closed down, but the state tenaciously kept to its pseudo-social profitability thesis tosupplement private initiative or to substitute for it where lacking. ${ }^{50}$ This was in a bid to safe-guard its patronage philosophy. ${ }^{51}$ The outcome was that the enterprises frustrated private domestic initiative and often prevented the few truly modern managers from rising. ${ }^{52}$ Besides,parastatals became more of liabilities than assetsas they scored incompatible results with regards to the means put at their disposal.

The deficits of parastatals were a great drain on the resources of the public sector. In order to arrest this situation, a programme of rational management in the public and semi-public sectors was drawn up with a view to reducing the pressure exerted on the state budget, thereby improving on their performances. To meet this vision, deductions were made on the state's budget during the 1986/87 financial year; from 850 billion francs CFA to 650 billion francs CFA in 1987/88 and to 600 billion francs CFA in the 1988/89 fiscal year. During this difficult period of the economy of Cameroon, a commission charged with rehabilitating unproductive state corporations was put in place with the responsibility of identifying those corporations that were either to be maintained, privatized or liquidated. ${ }^{53}$

As far as state corporations were concerned, the provisions of presidential Decree No. 87/1141 of 20 August 1987, was implemented, fixing remunerations and perquisites of staff in state and mixed

\footnotetext{
${ }^{44}$ C.A. Ngwa and C.M. Lambi, “An Evaluation of the Upper Nun Valley Authority's Agricultural Innovation in the Ndop Plain (Cameroon) since 1970," Epassa Moto(A Bilingual Journal of Arts, Letters and Humanities), Vol. 4, No.1( University of Buea, March 2009):51.

${ }^{45}$ JuaNantang, "Economic management in neocolonial states: A case study of Cameroon". Research paper No. 38 (Leiden: ASC, 1990).

${ }^{46}$ Awung and Atanga, "Economic Crisis and Multi-party Politics in Cameroon."104.

${ }^{47}$ Jua, "State, oil and Accumulation." 31.

${ }^{48}$ Konings, "The Post-Colonial State and economic and political reforms in Cameroon." 248-249.

${ }^{49}$ Awung and Atanga,"Economic Crisis and Multi-party Politics in Cameroon." 104

${ }^{50}$ G.M. Jürg, "Cameroon's Neopatrimonial Dilemma,"13.

${ }^{51}$ Jua,State, oil and Accumulation."33.

${ }^{52}$ Jürg, "Cameroon's Neopatrimonial Dilemma,"13.

${ }^{53}$ Fanso, History for Secondary Schools and Colleges, p.170.
} 
investment corporations. ${ }^{54}$ To this end, the salary scale of the public service was applied to all civil servants on secondment and casual bonuses, housing, touring, overtime, duty-post allowances, reimbursement of medical expenses, fuel allocation and vehicles were either cut down or suspended. Under the Agricultural sub-sector, a programme was earmarked covering the North West Region, for instance, designed to reduce post-harvest loses with assistance from the United Nations Development Programme (UNDP). ${ }^{55}$ It undertook sensitization campaigns and assured that sufficient quantities of improved seeds were placed at the disposal of farmers in good time.

Farmers were further drilled on the use of modern methods of production. ${ }^{56}$ In this way, a new system jointly financed by the state with USAID and EEC assistance ensured that fertilizers reached farmers in sufficient quantities and on time. This was in a way to reduce government expenditures in this direction, hardly ever being below 800 million francs CFA yearly, leading to a privatization of the fertilizer supply and distribution system ${ }^{57}$ In spite of these efforts by the state to solve the problems of state corporations, the commission charged with rehabilitating public corporations still identified some as unproductive and thus to be liquidated. ${ }^{58}$ The problem of the pitiable performance of the economy was not only informed by the parastatal ischemia, butalso, the opaque management and anticipations of the new found wealth.

\section{THE OIL ENIGMA}

Discussions on the performance of Cameroon's economy have most often projected the period running from the late 1970s when oil was discovered to the mid-1980s as the glorious height of the economy. In far more measure, this conclusion leaves much to be desired in substance because the addition of oil to the country's GrossDomestic Product (GDP) opened an inveterate debate between oil pessimists and optimists. Better still, it divided public opinion on two parallel lines as some perceived oil as a national blessing and others as a curse.

The prospection of oil reservesby the French exploration company, Elf-Aquitaine (SNEA) and later its local subsidiary Elf-SEREPC in the Rio del Rey belt of Cameroon which started way back in $1947^{59}$ and stretched up to the mid-1970s was inconsequential to the national economy. This is because, exploitation was very paltry. Oil production effectively started in 1978, with a total output of approximately 625,000 tons of crude oil. ${ }^{60}$ Granting its political entombment, there was no consistent records on the scale of oil production in Cameroon from the genesis of commercial production to the outbreak of the crisis in the mid-1980s, as can be seen on Table 1.

Table1. Cameroon Oil Production: 1978-1987(million tons)

\begin{tabular}{|c|c|c|c|}
\hline Year & NicodEstimates & International Oil Industry (IOI)Estimates & Other Estimates \\
\hline 1978 & - & 0.12 & 0.63 \\
\hline 1979 & 1.4 & 1.00 & 1.71 \\
\hline 1980 & 2.8 & 1.90 & 1.71 \\
\hline 1981 & 4.0 & 3.40 & 2.80 \\
\hline 1982 & 5.2 & 4.70 & 5.50 \\
\hline 1983 & 6.3 & 5.80 & 6.00 \\
\hline 1984 & 7.6 & 7.00 & 8.00 \\
\hline 1985 & 7.6 & 8.40 & 8.24 \\
\hline 1986 & 7.3 & 8.20 & 8.85 \\
\hline 1987 & 7.0 & 8.10 & 8.28 \\
\hline
\end{tabular}

Source:BikasC.Sanyal, Wilfred A. Ndongko et al., Development of the oil industry in Cameroon and its implications for education and training. (Paris: IIEP \&MESIRES, 1990):33.

\footnotetext{
${ }^{54}$ George FuhKum, "The Socio-Economic Impact of the Liquidation of the Wum Area Development Authority (WADA), on Wum Central, Sub-Division, 1989-2004”' (Maitrise Dissertation, History, University of Yaounde I, 2004$)$ : 61. ${ }^{55}$ Johnson NdarikwuGabuin, Former Director of WADA before Liquidation, 78 Years, Bamenda, $28^{\text {th }}$ August 2010

${ }^{56}$ Présidence de la République, Crise économique : Réponse du Cameroun, (Cabinet Civil, 1989) :17.

${ }^{57}$ Ibid., p. 18 .

${ }^{58}$ Interview with Joseph Ntangsi, Ex-Co- Director of the Wum Area Development Authority (WADA), 1970-1972, Former Representative of the KFW (German Development Bank) Yaoundé, 65 Years, Yaoundé, $3{ }^{\text {rd }}$ August 2010.

${ }^{59}$ Bernard Gauthier \&Albert Zeufack, Governance and Oil Revenues in Cameroon (London: OxCarre Research Paper 38, October 2009):7.

${ }^{60}$ JuaNantang, "State, oil and Accumulation," in P. Geschiere and P.Konings, Pathways to accumulation in Cameroon (Leiden: ASC, KARTHALA, 1993): 131.
} 
Besides the absence of consensus of official statistics on oil production, there was no specific legislation regulating the sector. Instead, activities in the sector were governed by the 1964 mining law (Loi 64-LF-3)supplemented by the 1978 Law (Loi 78-14). Under this regime, oil taxation in Cameroon was based on a complex system in many respectsunique in the world. At the start of oil production in 1977, the then President of Cameroon decided to create an extra-budgetary account ("Compte Hors-Budget" CHB) a board, to manage oil revenues. ${ }^{61}$ This decision according to Jua was enigmatic because export revenues from the sale of cash crops were always 'budgeted. ${ }^{, 62}$ Cameroon's decision to "save" its oil reserves abroad is argued, was sound for at least two reasons: first, to help in avoiding oil dependence and the Dutch disease and secondly, because its boom was allegedly temporary as the rate of depletion of oil was believed to be very high. ${ }^{63}$

From a political economy perspective, the cautious approach by the post-colonial state to the 'oil debate' was attributed to its determination to adhere to the course of 'conservatism' on such issues. Symptomatic of this policy was the throttling of structural economic transformation if it could engender political tensions, disrupt the apparent equilibrium that existed between the regions or socioeconomic groups and ultimately threaten the power of the state. ${ }^{64}$ In this spirit of totalitarianism, the state made the oil economy sacrosanct and secret. Gutrai and Zeufack carefully observe that:

Instead of depositing 65 percent of its reserves in the "Compted'Opérations" in the French treasury, as per the CFA zone rules, President Ahidjo decided to keep a portion of oil revenues in US Dollars, in "escrow accounts" in foreign banks. The motivation announced then was to "avoid oil dependence" but also to have a "War Chest" (trésor de guerre), a fund for special projects... 65

This balance was supposed to be placed in the extra-budgetary account. While there is evidence that the country's investment budget was funded mostly by resources from the "extra budgetary account" between 1980 and 1986, ${ }^{66}$ serious mismanagement occurred. Building on the opacity and secrecy around the account and oil production in Cameroon ${ }^{67}$ and in spite of the fact that oil production in Cameroon peaked at about 65 million barrels per year around $1985-1986,{ }^{68}$ the manifestation of the economic crisis was inevitable. This was due in part to the fact that huge funds of the CHB were invested in unproductive parastatals. Illustrative of this financial drain was the increase in the funding of SODECAO from 200 million FCFA in 1982/1983 to an astronomical figure of 11.82 billion FCFA in $1984 / 1985 .^{69}$

It is worth mentioning that in 1983, a few months after the investiture of Paul Biya as the second President of the country, an attempt was made through his "New Deal Policy" ${ }^{10}$ to reverse the status quo on national oil management. This was initially done through a public policy discourse where he intimated that:

"...if the accounts of oil revenue were not immediately included in the national budget, this was for technical reasons... But we will continue to discuss the best ways of presenting these receipts which are public receipts and belong to the entire Cameroonian nation". ${ }^{71}$

This was the first time in the history of the oil debacle that such a subtle proclamation was made by a top state functionary. It marked a great departure from President Ahidjo's conservatism. However, the hope that President Biya's intended reversal of rule raised was ephemeral. From 1983 to 1987 when the crisis was officially announced, transparency remained an intractable problem as oil revenues

\footnotetext{
${ }^{61}$ Ibid., 8.

${ }^{62}$ Jua, "State, oil and Accumulation." 137.

${ }^{63}$ Gautraiand Zeufack,Governance and Oil Revenues in Cameroon. 23.

${ }^{64}$ Jua, "State, oil and Accumulation." 138.

${ }^{65}$ Gutrai and Zeufack, 23.

${ }^{66}$ Projects such as the Douala-Yaoundé and Yaounde-Bafoussam highways: Airports in Bamenda, Garoua and Bafoussam, high-rise office buildings and international hotels in Yaoundé and Douala were undertaken thanks to revenue from oil. Oil revenue financed about 50\% of public capital expenditures. See Jua,State, oil and Accumulation.” 140-141. ${ }^{67}$ Ibid.

${ }^{68}$ Gutrai and Zeufack, Governance and Oil Revenues in Cameroon.15.

${ }^{69} \mathrm{Jua}$, State, oil and Accumulation."150.

${ }^{70}$ This philosophy was centred on the principles of rigour and moralisation and communal liberalism

${ }^{71}$ Jua, "State, oil and Accumulation." 138-139.
} 
were still not incorporated into the state budget in spite of the persistent advice from the International Monetary Fund (IMF) to do so for a more rational planning and programming process. The decision to manage the oil revenue on blind and expediency considerations only gave space for conspicuous consumption, endemic corruption, embezzlement and capital flights. ${ }^{72}$

\section{CONClusion}

Economic performance can hardly be discussed independently from the actors that contribute to it. Broadly speaking, economic planning and investment may either be appreciated from the private and public sectors perspectives or a kaleidoscope of the two. At the level of the state, a key question that arises is who controls the economy and who sets the rules. It is on this premise that the economy of Cameroon took many changes in its growth process during the period running from 1960 to 1986. However, the years that characterized real economic growth were those which ran from 1980 to 1986 with an average rate of 3 to 5 percent per annum. This was marked by increased anticipation of productive projects in the country's five years development plans and the exploitation and exportation of petroleum products. The economic crisis was a downturn to this trend in the country's economy in the mid-1980s. The crisis undoubtedly was nursed during the First Republic when state-centric practices associated with patronage economic control downplayed the quintessence of Development plans. The social profitability thesis of creating parastatals and the opaque, secret and politicalcharged management of oil revenues by the state only culminated to sponging the economy from its productive resources. The government'sdeclaration of an escalation of the crisis in 1987 from the fall of prices of export commodities especially in the price of petroleum products was more or less a consolatory eulogy for an inspiring economic project that was ruined by "bad manners" in execution.It is on this premise that the article vouched that Cameroon's economic performance from independence to the outburst of the economic crisis was a curse of state capitalism.

\section{REFERENCES}

[1] Ahidjo, A. The Political Philosophy of Ahmadou Ahidjo.1958-68. Monte Carlo: CNU Political Bureau, 1968.

[2] _ Ahidjo, As Told by AhmadouAhidjo.Monaco: Editions Paul Bory, 1968.

[3] __ Fondements et perspectives du Cameroun. Paris : Saint Lambert, 1976.

[4] Amin A. A. (Ed.). "Cameroon's economy and reforms in developing a sustainable economy in Cameroon."Dakar: CODESRIA, 2008.

[5] Anderson, P. and Lorch, R.P. Agricultural growth is the key to poverty alleviation in Low Income Developing Countries, in the Unfinished Agenda: Perspectives on overcoming Poverty and Environmental Degradation (Washington D.C, 2001).

[6] Awung ,W. J. and Atanga, M. "Economic Crisis and Multi-party Politics in Cameroon," Cameroon Journal of Democracy and Human Rights, Vol 5. No. 1 (June 2011): 94-127.

[7] Bertelsmann, Stiftung. Cameroon Country Report, BTI, 2012, in http://www.bti-project.org, retrieved on 20/07/2013.

[8] Douya, E. "Cotton Supply Response in Cameroon", in (CODESRIA, Dakar, 2008):66.

[9] Fanso, V.G. Cameroon History for Secondary Schools and Colleges, Vol 2: The colonial and post-colonial periods. London and Oxford: Macmillan Cameroon, 1989.

[10] Gauthier, Bernard andZeufack, Albert.Governance and Oil Revenues in Cameroon. London: OxCarre Research Paper 38, October 2009.

[11] Henry, P. M. "The United Nations and the Problem of African Development", International Organization, XVI, No. 2, (Spring 1962).

[12] Jürg, M.G. "Cameroon's Neopatrimonial Dilemma," Working Paper No. 20.Zurich: Center for International Studies, August 1999.

[13] Konings, P.J.J., "The Post-colonial State and economic and political reforms in Cameroon," inJilberto, A.E. Fernández and Mommen, A. (Eds.). Liberalization in the developing world: institutional and economic changes in Latin America, Africa and Asia. London/New York: Routledge, 1996.

[14] Kum, George Fuh, "The socio-economic impact of the liquidation of the Wum Area Development Authority (WADA), on Wum Central, Sub-Division, 1989-2004" (Maitrise Dissertation, History, University of Yaounde I, 2004).

\footnotetext{
${ }^{72}$ Ibid., 138-150.
} 
[15] LeVine, V.T. , The Cameroon Federal Republic. Ithaca and London: Cornell University Press, 1971.

[16] Mboudou, A.M. «Le financement du développement au Cameroun » (Thèse de Doctorat de 3éme Cycle, Sciences Economiques, Université de Yaounde, 1981).

[17] Nantang, Jua. "Economic management in neocolonial states: A case study of Cameroon". Research paper No. 38. Leiden: ASC, 1990.

[18] Ndongko, A. W.Planning for Economic Development in a Federal State: The Case of Cameroon, 1960 1971. Munchen: Welt Form Verlage, 1975.

[19] _. "Regional Economic Planning in Cameroon", Research Report No. 21. Uppsala: The Scandinavian Institute of African Studies, 1974.

[20] _. Labour Resistance in Cameroon: Strategies and Labour Resistance in the Agro-Industrial Plantations of the Cameroon Development Corporation. Leiden: African Studies Centre, 1993.

[21] _. Regional Development Policy in Cameroon (Faculty of Law and Economics University of Yaoundé, 1975).

[22] Ngango, G.Les investissements D'origine extérieur en Afrique noire Francophone: Statut et incidence sur le développent .Paris :PrésenceAfricain, 1973.

[23] Ngwa C.A. and Lambi , C.M., “An Evaluation of the Upper Nun Valley Authority’s Agricultural Innovation in the Ndop Plain (Cameroon) since 1970," Epassa Moto(A Bilingual Journal of Arts, Letters and Humanities), Vol. 4, No.1 ( March 2009).

[24] Philippe, H.Analyse du sous-développement en Afrique noire: l'exemple de l'économie du Cameroun. Paris : Presses Universitaires de France, 1968.

[25] Pollock, Friedrich. "State Capitalism: Its possibilities and limitations" in Arato,Andrew and Gebhardt, Eike.Eds.The Essential Frankfurt SchoolReader.New York: Continum, 1982.

[26] Présidence de la République, Crise économique : Réponse du Cameroun, (Cabinet Civil, 1989).

[27] Rodney,Walter. How Europe Underdeveloped Africa. London: Bogle-L'Ouverture Publications, 1972.

[28] Seitz, J.The Politics of Development.New York:Basil Blackwell Inc, 1988.

[29] Sikod, F. "The Completion point of the HIPC Initiative: what it means for the Cameroon Economy, A Presentation at Hilton, Sponsored by the British Council" (2006).

[30] Tchoungui, R., Gartlan, Steve, et al., "Structural adjustment and sustainable development in Cameroon." London: ODI Working Paper 83, August 1995.

\section{Interviews}

[31] Johnson NdarikwuGabuin, Former Director of WADA before Liquidation, 78 Years, Bamenda, 28 ${ }^{\text {th }}$ August 2010.

[32] Joseph CheKangolo, 70 Years (Interview) Former Secretary of State for Interior, West Cameroon, Wum, $23^{\text {rd }}$ November 2006.

[33] Joseph MgbwahNgoh, 64 Years (Interview) WADA Extension Carpenter, Wum, 5th January 2010.

[34] Joseph Ntangsi, Ex-Co- Director of the Wum Area Development Authority (WADA), 1970-1972, Former Representative of the $K F W$ (German Development Bank) Yaoundé, 65 Years (Interview) Yaoundé, $3^{\text {rd }}$ August 2010.

\section{Archival Documents}

[35] National Archives Buea(NAB), Cameroon

[36] File No. PMO 422 (Qb/a 1962/2), "General Economic Situation in West Cameroon Arising from Reunification", (1962):92.

[37] File No. 271/ S.2 (Qb/a 1969), “Third Five Year Development Plan, 1971-76”, (1969):148.

[38] File No. DVA/J.2/2, (Qb/a 1960), "Five Years Development Plan" (1960): 3.

\section{AUTHORS' BIOGRAPHY}

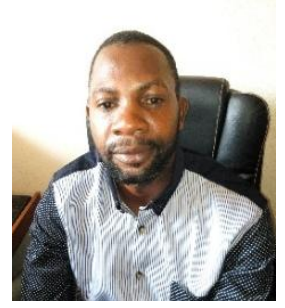

Dr. Nixon KahjumTakor is currently lecturer of History and Chair of the Department of History and Archaeology at the Faculty of Arts, The University of Bamenda in Cameroon. He is a member of the Business History Congress and the Cameroon History Society. His teaching and research interests over the years has centered on aspects of economic and social history, public history, didactics of history, historiography and historical research methods. 


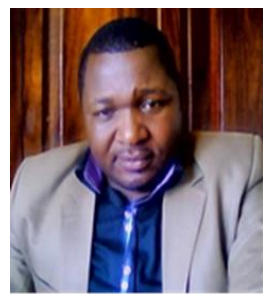

Dr. George Fuh Kum is a Senior lecturer at the Department of History in the Faculty of Arts, Letters and Social Sciences of the University of Yaounde I, Cameroon. $\mathrm{He}$ is a member of the Architectural and Humanities Research Association, Cameroon History Society and Global Association for Humanities and Social Science Research. His teaching and research missions is focused on economic and social history, international economic cooperation and geo-strategic studies.

Citation:Nixon KahjumTakor, Ph.D., George FuhKum, Ph.D. "Incubation of the Economic Crisis in PostColonial Cameroon 1960-1987: An Experience in State Capitalism" International Journal of Humanities Social Sciences and Education (IJHSSE), vol 5, no. 8, 2018, pp. 54-65. doi: http://dx.doi.org/10. 20 431/23490381.0508008 .

Copyright: (C) 2018 Authors. This is an open-access article distributed under the terms of the Creative Commons Attribution License, which permits unrestricted use, distribution, and reproduction in any medium, provided the original author and source are credited. 